Some time ago I communicated the above information to Dr. K. Wodzicki, Wellington, New Zealand, who during his visit in 1974 to Poland told me he had been informed that bats still occurred at Mangaia. The geographical position of Mangaia is $21^{\circ} 55^{\prime} \mathrm{S}, 157^{\circ} 55^{\prime} \mathrm{W}$. Its bats seem to belong to Pteropidae although they are intriguingly small. The probable presence of bats on this island deserves close investigation as it seems to extend the geographical range of the Polynesian bats $1282 \mathrm{~km}$ EES from Niue I.

Some ethnographical and geographical publications probably contain even more information unknown to mammalogists on bats of the Pacific islands. One should attempt to verify them as soon as possible as those bats are endangered by eradication.

\title{
REFERENCES
}

R y berg O., 1947: Studies on bats and bat parasites. Bokförlaget Svensk Natur. 1-330. Stockholm. Wodzicki K. \& Felten H., 1975: The Peka, or fruit bat (Pteropus tonganus tonganus) (Mammalia, Chiroptera), of Niue Island, South Pacific. Pacific Sci., 29, 2: 131-138. S m it h S. P., 1902: Niue Island and its people. J. Polynes. Soc., 11: 81-106. Gill W. W., 1876: The Mammalia of the Pacific. The Leisure Hour, 1876: 308-309.

Accepted, July 5, 1976 .

\section{Contribution to the History of Bats on Iceland}

Przyczynek do historii nietoperzy na Islandii

\author{
Adam KRZANOWSKI
}

\begin{abstract}
Krzanowski A., 1977: Contribution to the history of bats on Iceland. Acta theriol., 22, 19: 272-273.

The paper calls attention to the overlooked and oldest source on Icelandic bats and gives the evidence in favour of the view that some 200 years ago the American species Lasiurus cinereus (B e a u vo is, 1796) got to Iceland by wing.

[Inst. Syst. Exp. Zool., Polish Acad. Sci., Slawkowska 17, 31-016 Kraków, Poland]
\end{abstract}

Records of Icelandic bats were reviewed by Koopman \& Gudmunds on (1966) who suppose that individuals of Lasiurus cinereus are driven there by storms. Other investigators, however, as $\mathrm{H}$ a y $\mathrm{m}$ a $\mathrm{n}$ (1959) do not consider it as certain because all the findings took place when the human transport was already well developed. Therefore it should be noted that the bats were known in Iceland already in the 18th century. P e n n a n t (1784, p.L) states: »The Common Bat, ... is sometimes found in this island ...", p. CLXXXII. "... the Common Bat was originally tempest-driven to the latter (Iceland) from Norway". In the same book, 
Suppl., p. 185 (1787a) we read: "This species (Common Bat) is found in Iceland, as I was informed by the late Mr. Fleischer, which is most northerly residence of this genus". The German edition of the above book, by $\mathrm{Z}$ immermann $(1787 \mathrm{~b}$, p. 180) gives the Latin name of Common Bat as »Vespertilio (murinus) ... Linn. Syst. 47«. Although Ryberg $(1947$, p. 49,79$)$ states that the term "Common Bat « was once applied to several bat species it will be pointed out below that the species meant by Pennant was probably $V$. murinus L in na e us, 1758 . It is the wide-spread Palearctic species, known also in Norway, and is at the first sight similar to L. cinereus as both have frosted fur. Although these species differ in size the weight of $V$. murinus being about that of Lasiurus borealis (M üller, 1776), an error in determination of Icelandic bats probably occurred which was quite understandable in the 18 th century; besides, $L$. cinereus was not yet known to science. The further evidence in favor of this view is the fact that out of the five bat specimens found recently in Iceland four are $L$. cinereus and the fifth one is not $V$. murinus. The last species is by far not so strong a flier as L. cinereus and its flight to Iceland from Scandinavia would have to occur against the prevailing winds. There is no reason to suspect that Iceland has been mistaken for some other island. The above mentioned evidence allows us to conjecture that $L$. cinereus visited Iceland by wing some two hundred years ago, as it is hardly probable that it was a stowaway because of its habits and poorly developed ship transport in those times.

\section{REFERENCES}

Ko opman K. F. \& Gudmundsson F., 1966: Bats in Iceland. Amer. Mus. Novit., 2262: 1-6. H a y m a n R. W., 1959: American bats reported in Iceland. J. Mammal., 40, 2: 245-246. P ennant Th., 1784: Arctic Zoology, 1: CC+1-185. London. Pennant Th., 1787a: Supplement to the Arctic Zoology, London. Pennant Th., 1787b: Thiergeschichte der Nördlichen Polarländer - Aus dem Englischen des Herr Thom. Pennant, mit Anmerkungen und Zusätzen durch E. A. W. Zimmermann. 1-185. Leipzig. R y berg O., 1947: Studies on bats and bat parasites. Bokförlaget Svensk Natur. 1-330. Stockholm.

Accepted, July 5, 1976. 